\title{
Determinants of Unsafe Behavior in Pesticide Usage among Horticulture Farmer
}

\author{
Eka Lestari Mahyuni ${ }^{1 *}$, R. Hamdani Harahap ${ }^{2}$, Urip Harahap ${ }^{3}$, Nurmaini Khalik ${ }^{4}$ \\ ${ }^{1}$ Department of Occupational Safety and Health, Faculty of Public Health, Universitas Sumatera Utara, Medan, Indonesia; \\ ${ }^{2}$ Department of Social Anthropology, Faculty of Social and Politics, Universitas Sumatera Utara, Medan, Indonesia; ${ }^{3}$ Department \\ of Pharmacology, Faculty of Pharmacy, Universitas Sumatera Utara, Medan, Indonesia; ${ }^{4}$ Department of Environmental Health, \\ Faculty of Public Health, Universitas Sumatera Utara, Medan, Indonesia
}

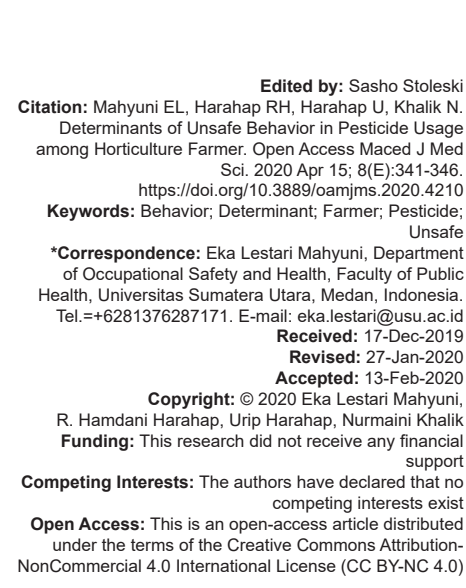

\section{Introduction}

Population growth is in line with horticultural commodities demand and enhancement. The efforts to intensify agriculture by various technologies are encouraged to optimize the agricultural product, through pesticide use. The increasing use of pesticides is certainly followed by higher pesticide exposure and toxicity for agricultural workers, especially pesticide sprayers [1], [2], [3].

The act of processing, mixing, and spraying of pesticide might bring several health problems. Farmer's orientation in pesticides use is generally just focused on controlling the crop pests. Pesticide use in daily makes farmer's in ignore their safety and environment aspect, also assume that the pesticide as harmless things. It shows from the worse pesticide behavior such as seldom wear the personal protection equipment (PPE), smoking while spraying, littering the pesticide package, and others so that the contact with pesticide often happens [4], [5], [6].

The World Health Organization (WHO) estimates that around 108,000 deaths occur due to poisoning and pesticide in one of the reasons. The number also relatively high in poor and developing countries. Pesticide poisoning is ranked in the top five nationally in Indonesia. Based on the research in Indonesia, there are 168 poisoning cases and 96 cases lead to death. The pesticide poisoning cases that happen in Indonesia were not reported accurately, so the amount is higher than the number reported. Based on the pesticide toxicity examination in Karo District, it was found that there were $69.13 \%$ pesticide toxicity at farmers in Deram Village, Merdeka sub-district, 63.09\% in Barung Kersap Village, Munte sub-district, approximately $91.25 \%$ in Kacinimbun village, Tiga Panah sub-district, $55.26 \%$ in Paribun village, Barusjahe sub-district, and $91.25 \%$ in Sugihen village, Dolat Rakyat sub-district [7], [8], [9], [10]. 
Sumber Mufakat is the village that farmers produce lots of horticulture crops are quite frequent of pesticide use because these plants are very vulnerable to pest attack. Based on the preliminary survey, it is found 6 farmers from 55 who examined that have a level of enzyme cholinesterase close to the allowed limit value. There are 51 farmers showed the symptoms of mild to moderate poisoning. Smoking habits are very high in Sumber Mufakat village community where the majority of 35 peasants smoke $5-50$ cigarettes a day. Smoking habits are also often done while spraying pesticides so that the risk of inhalation is very likely to occur, added without using personal protection [11].

Actually, in pesticide application, there were no farmers improper with the procedure and it gives the high potential risk of toxicity. The purpose of this study is to analyze the determinants of unsafe behavior in pesticide usage among horticultural farmers.

\section{Methods}

This study used a mixed-method that conducted in Sumber Mufakat Village, Kabanjahe sub-district, Karo Regency. The majority of farmers use the pesticide in improper procedures. This phenomenon increased the risk of toxicity with a high impact on occupational health and needs to be prevented. Ethical clearance has been proposed and used by fulfilling the factor of autonomy, beneficence, and non-maleficence or does not harm and confidentiality of the ethical institutions.

The population is $\mathbf{5 0 5}$ farmers that found from farmer's group in Sumber Mufakat villages [12]. The sample size of the population is 83 farmers who use pesticides. It distributed representative on nine hamlets that divided into two main areas Sumbul and Berhala. Data collected by in-depth interview and focus group discussion based on behavioral determinants according to predisposing factor, enabling factor, and reinforcing factor.

The analytical study was carried out in qualitative and quantitative. The qualitative data were analyzed by domain of Lawrence Green's concept and quantitatively analyzed using the Chi-square test [13], [14], [15], [16], [17], [18].

\section{Results and Discussion}

Kabanjahe as sub-district in Karo District, North Sumatra Province, located in tropical climate and consists of 13 villages including Sumber Mufakat village. Majority of people in this Sumber Mufajat village work as farmers. Most farmers grow a horticultural plant such as broccoli, potatoes, carrots, beans, chillies, and tomatoes. The dominant plant was flower chrysantheum and cabbage in their field. The intercropping method in horticulture farming making farmers tends to use various types of pesticides. The crops that they growth also classified as pest vulnerable plant making farmers use pesticides in high frequency with various type of pesticide which bring the risk for their health. Farmers have also exposed pesticides for a long time. Based on the interview, the farmers told that most of them have contact with pesticide from childhood caused they help parents in the field. The characteristic of farmer as the sample found in this research could be seen in Table 1.

Table 1: Frequency distribution of characteristics of horticultural farmers in Sumber Mufakat village

\begin{tabular}{lll}
\hline Variable & Frequency & Percentage \\
\hline Age (years old) & 14 & \\
$<30$ & 32 & 16.9 \\
$30-39$ & 14 & 38.6 \\
$40-49$ & 12 & 16.9 \\
$50-59$ & 11 & 14.5 \\
$>59$ & & 13.3 \\
Sex & 28 & 33.7 \\
Female & 55 & 66.3 \\
Male & & \\
Education & 15 & 18.1 \\
Elementary school & 25 & 30.1 \\
Junior high school & 39 & 47 \\
Senior high school & 4 & 4.8 \\
Diploma & & \\
Duration as a farmers (years) & 14 & 16.9 \\
$<10$ & 36 & 43.4 \\
$10-19$ & 14 & 16.9 \\
$20-29$ & 19 & 22.9 \\
$>29$ & 83 & 100.0 \\
Total & & \\
\hline
\end{tabular}

Based on the research, the farmer has good experience in pesticide use. Most farmers have to use pesticide in 10-19 years amount of 36 farmers (43.4\%) even 19 farmers (22.9\%) have use pesticide for more than 29 years (Table 1). Dependence on pesticides could not be avoided and has become hereditary in this community. Although they have high education or working in government, all of the community have the field and use the pesticide in daily activity.

Therefore, farmers rarely use pesticide incorrectly caused that they assume the pesticide did not give the direct impact for them. Based on the in-depth interview, farmers said that they feel dizziness and headache, itchy, and hot at the skin. However, the symptoms will disappear and farmers felt accustomed to the symptom and ignored it.

The longer pesticide exposure will bring the health effect and generally as a chronic toxicity. It more difficult to detect caused, it is not immediately felt, does not cause symptoms and giving the specific sign. The health problem as chronic toxicity that often associated with pesticide uses among farmers are irritation, cancer, miscarriage, defect in babies, nervous symptom, heart, kidney, and respiratory system. Based on literary study, the effect of pesticide use could cause multiple myeloma, sarcoma, prostate cancer and pancreas, cervix cancer, breast cancer, neurobehavioral, and Hodgkin [19], [20], [21], [22]. 
The pesticide use in this community categorized as unsafe behavior on 48 farmers (57.8\%) of 83 as a sample. The safety indicator included the improper behavior of farmers like direct contact when mixing the pesticide, callibration of spraying hoes, and spraying risk behavior. The unavoidable of exposure usually caused by splattered when spraying, unfollowed the wind direction and inhalation of pesticide drops. The other behaviors have to concern that is the lack of farmer aware to save pesticide disposal. The farmer usually littering around fields or into ravines and leaving the remaining pesticide in the spraying tools to be reused the next day. This phenomenon implied the high risk of pesticide exposure cause it can polluted the environment and improved the symptom of toxicity due to direct exposure even more never use the PPE while spraying. It means the pesticides are considered the greatest danger at their work. Farm workers appear to be a closed community with a high disease burden. Farmers of Sumber Mufakat were exposed to highly hazardous, restricted, and banned pesticides, with insufficient protection [23], [24], [25].

\section{The domain of predisposing factor in pesticide unsafe behaviors}

The predisposing determinant that pushed the improperly used in this research is knowledge, attitude, habit, culture value, and social status. According to the research, the farmers have poor knowledge in 47 farmers $(48.7 \%)$ and show the unsafe pesticide use in 48 farmers $(57.8 \%)$. It has a significant association between knowledge and pesticide use $(p=0.000)$. Cognitive is an important domain to create the action of farmers. It self-shaping a person's positive or negative attitudes toward something. A person's attitude means weather they support or against the specific things [26], [27].

The majority of farmers who use pesticide unsafety are the one who shows the negative attitude for 35 farmers (42.2\%). Statistical analysis found a significant relationship between farmer's knowledge that contributed in unsafe pesticide used. It correlates with observation where most farmers who show a positive attitude with pesticide dependence make unsafe behavior. It formed related to education basic and incorrectly knowledge about the risk of pesticide use. It means that the farmer has no care although the training has given to create them aware of pesticide hazard [1], [9], [28], [29].

The habit in pesticide is poor and unsafe around 56 farmers $(67.5 \%)$. Continuously habit could create a poor culture in pesticide use that shown at this village (Table 2). Habit and culture have a significant correlation ( $p=0.000$ ). In general, the habit as risk potential of toxicity happens caused by poor knowledge among farmer that usually followed their partner's experience when used the pesticide. In other hand, the farmer believes that the higher price of pesticide more pays attention rather than the effects of a chemical that will be experienced.

Table 2: The domain of unsafe behavior determinants in pesticide usage among farmers

\begin{tabular}{|c|c|c|c|c|c|c|c|}
\hline \multirow[t]{3}{*}{ Variable } & \multicolumn{4}{|c|}{ Pesticide usage } & \multirow{2}{*}{\multicolumn{2}{|c|}{ Total }} & \multirow[t]{3}{*}{ Sig-p } \\
\hline & \multicolumn{2}{|c|}{ Safe } & \multicolumn{2}{|c|}{ Less } & & & \\
\hline & $\mathrm{n}$ & $\%$ & $\mathrm{n}$ & $\%$ & $\mathrm{n}$ & $\%$ & \\
\hline \multicolumn{8}{|c|}{ Domain predisposing factor } \\
\hline \multicolumn{8}{|c|}{ Knowledge } \\
\hline Good & 19 & 22.9 & 7 & 8.4 & 26 & 68.7 & \multirow[t]{2}{*}{0.000} \\
\hline Less & 16 & 19.3 & 41 & 49.4 & 57 & 31.3 & \\
\hline \multicolumn{8}{|l|}{ Attitude } \\
\hline Positive & 19 & 22.9 & 13 & 15.7 & 32 & 38.6 & \multirow[t]{2}{*}{0.022} \\
\hline Negative & 16 & 19.3 & 35 & 42.2 & 51 & 61.4 & \\
\hline \multicolumn{8}{|l|}{ Habit } \\
\hline Good & 19 & 22.9 & 8 & 9.6 & 27 & 32.5 & \multirow[t]{2}{*}{0.000} \\
\hline Less & 16 & 19.3 & 40 & 48.2 & 56 & 67.5 & \\
\hline \multicolumn{8}{|c|}{ Culture factors } \\
\hline Good & 20 & 24.1 & 8 & 9.6 & 28 & 37.7 & \multirow[t]{2}{*}{0.000} \\
\hline Less & 15 & 18.1 & 40 & 48.2 & 55 & 66.3 & \\
\hline \multicolumn{8}{|c|}{ Social status } \\
\hline Good & 17 & 20.5 & 8 & 9.6 & 25 & 30.1 & \multirow[t]{2}{*}{0.003} \\
\hline Less & 18 & 21.7 & 40 & 48.2 & 58 & 69.9 & \\
\hline \multicolumn{8}{|c|}{ Domain enabling factor } \\
\hline \multicolumn{8}{|c|}{ Availability of personal protection equipment } \\
\hline Good & 18 & 21.7 & 4 & 4.8 & 22 & 26.5 & \multirow[t]{2}{*}{0.000} \\
\hline Less & 17 & 20.5 & 44 & 53.0 & 61 & 73.5 & \\
\hline \multicolumn{8}{|c|}{ Working tools } \\
\hline Good & 21 & 25.3 & 3 & 3.6 & 24 & 28.9 & \multirow[t]{2}{*}{0.000} \\
\hline Less & 14 & 16.9 & 45 & 54.2 & 59 & 71.1 & \\
\hline Health facilit & & & & & & & \\
\hline Good & 22 & 26.5 & 17 & 20.5 & 39 & 47.0 & 0.016 \\
\hline Less & 13 & 15.7 & 31 & 37.3 & 44 & 53.0 & \\
\hline Availability c & & & & & & & \\
\hline Good & 21 & 25.3 & 9 & 10.8 & 30 & 36.1 & 0.000 \\
\hline Less & 14 & 16.9 & 39 & 47.0 & 53 & 63.9 & \\
\hline Domain reinfo & & & & & & & \\
\hline Community & & & & & & & \\
\hline Good & 18 & 21.7 & 9 & 10.8 & 27 & 32.5 & 0.002 \\
\hline Less & 17 & 20.5 & 39 & 47.0 & 56 & 67.5 & \\
\hline Partner sup & & & & & & & \\
\hline Good & 12 & 14.5 & 4 & 4.8 & 16 & 19.3 & 0.004 \\
\hline Less & 23 & 27.7 & 44 & 53.0 & 67 & 80.7 & \\
\hline Agriculture & & & & & & & \\
\hline Good & 18 & 21.7 & 8 & 9.6 & 26 & 31.3 & 0.002 \\
\hline Less & 17 & 20.5 & 40 & 48.2 & 57 & 68.7 & \\
\hline Health provi & & & & & & & \\
\hline Good & 27 & 32.5 & 13 & 15.7 & 40 & 48.2 & 0.000 \\
\hline Less & 8 & 9.6 & 35 & 42.2 & 43 & 51.8 & \\
\hline Total & 35 & 42.2 & 48 & 57.8 & 83 & 100.0 & \\
\hline
\end{tabular}

It formed the assumption which the expensive pesticide better than the cheapest one even has the same content. This habit potential makes the farmer increased the dose and frequency of spraying. Hence, the amount of toxicity risk depends on the type of pesticide. Based on observation, the farmers always use the pesticide to exceed the safe limit allowed [5], [28], [29], [30].

The unwise of pesticide use bring negative impacts on health. It depends on many factors such as the type of pesticide, dose and frequency of spraying, work period as a sprayer, duration of spraying, PPE, pesticide method, last contact with pesticide, plant height, temperature, sprayed time, and wind direction [5], [31], [32], [33], [34]. The combination with inadequate knowledge and practice among the farmers has posed a danger of acute intoxications, chronic health problems, and environmental pollution [35].

\section{The domain of enabling factor in pesticide} unsafe behaviors

The enabling factor that contributed to unsafe pesticide use analyzed based on availability PPE and 
pesticide, working tools, and health facilities in the village. In generally, PPE does not need in applicable standards. Farmers more prefer to use hats and boots when using pesticide in daily. Sometimes, they do not use any shoe and use a sarong hat for coverage. These habits show the original character of the people in this village (Figure 1).

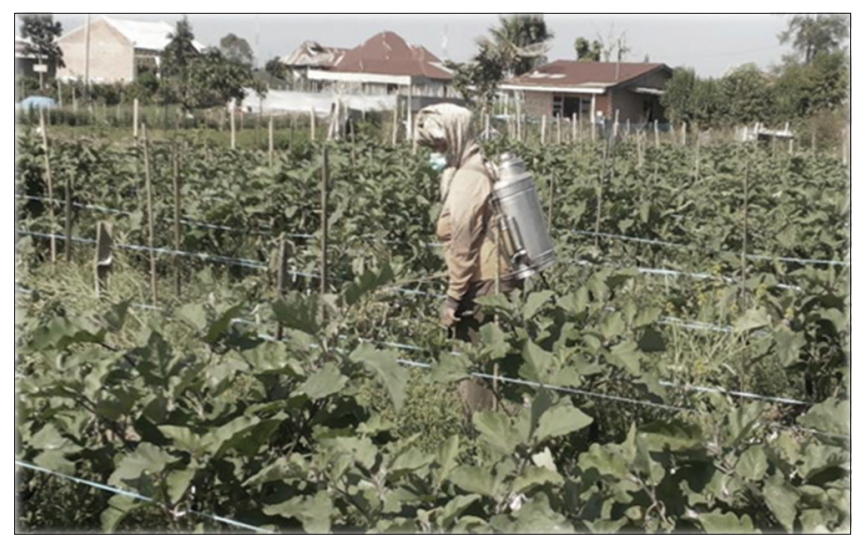

Figure 1: Personal protection showed the characteristic of community

There are no special clothes for spraying caused the farmers usually used the layered clothing to suit with the mountain cool air temperature. Statistical analyzed that PPE and pesticide availability, working tools, and health facilities have a significant correlation with pesticide use. In actually, all facilities have available in good condition but that is still unsafe using by the farmers. Pesticide availability could be quite free and lack of government-controlled. In here, the farmers could act as a seller of pesticide with promoting the pesticide in their field with direct application cause the bonus promotion from distributor. In other hands, even the farmer has the PPE, they always forgot to use it. The farmer has a good working tools caused it is to be their needed, but it concludes that sometimes the farmer careless and not discipline to save their health and it showed by careless of the pesticide risk and effect.

The PPE negligence behavior is one of the determinants who will cause unavaoidable exposure of pesticide directly to the port of the entry such as skin, mouth, and respiratory system. Furthermore, exposure mostly happens when mixing and spraying the pesticide [5], [36], [37], [38].

Based on observation, the farmer more used the organophospat and paraquat type of pesticide. To throw away the grass in land preparation, the farmer using Gramoxon with organochlorin content that has the high risk to exposure. It is possible to pesticide polluted the field and influence the productivity of horticulture plant. The effect of pesticide giving the symptom such as allergy and fatique. Some hazard giving the short effect such as irritation, headaches, dizziness, and nausea to chronic impacts such as cancer, diabetes, heart disease, and asthma. The risks are difficult to elucidate due to the involvement of various factors. In addition, the risk of pesticide exposure is strongly associated with farmers' behavior when working with pesticides. The WHO has recommended that access to highly toxic pesticides be restricted. Need to know the farmers in this village usually used a compound of pesticide. They can mixed three or more pesticide for one sprayed depend on the kind of organism attack. Interaction of the compound could be giving the strongest effect or others such as resulting estrogenic effects. The promotion of organophosphate induced delayed polyneuropathy. It is shown by fatique symptom and stunting syndrome [39], [40], [41], [42].

The availability of health facilities (Puskesmas) has a significant relationship with pesticide use $(p=0.016)$. It describes that farmers rarely use the health facilities. The farmers more concerned with agricultural facilities and technology to support their cultivation. Even though farmers exposure to pesticides, they rarely use health facilities. They assume that symptoms are reversible and temporary so require no further treatment.

This complexity problem depends on the government program to reduce the toxicity at the farmer community. Cause awareness to use PPE was depend on the character of the community to protect their health from pesticide exposure. Risk perception was strongly associated with behavior; farmers concerned about specific health problems were much more likely to use protective equipment [43].

Rather than simply focusing on knowledgebased strategies, comprehensive interventions are needed to reduce both exposure and health risks, including training, improvements in labeling, measures to reduce cost barriers to the adoption of safe behaviors, promotion of control measures other than PPE, and support for integrated pest management [35].

\section{The domain of reinforcing factor in pesticide unsafe behaviors}

The reinforcing factor as unsafe behavior determinant in pesticides used analyzed base on the support of community leaders, partners, agricultural providers, and health providers. These factors have a significant correlation with the pesticide use behavior where the factors giving the special role in pesticide use by farmers. Community leaders have a role in reminding the safe pesticide use. It is possible to community leader caused they also have the same profession as farmers and sometimes act like partners of farmers. Agriculture and health providers generally play a role in socialized safety and health security in pesticides use. Thus, both of them have to support and create the safety behavior of pesticide use.

This study showed that there is a lack of support that is mentioned above, leads to unsafe behavior while using the pesticide. It causes the support provided is not carried out continuously. The farmers tend to return to their daily habit. The lack of supervision while using pesticides also makes farmers stick to their 
own decisions when using pesticides. As a result, the danger caused using pesticide not in accordance to safety procedure become high and significant.

Therefore, it is necessary to evaluate a policy which generally shows that it has not been effective and efficience to satisfying the farmer's group as pesticides user [44]. It requires the revitalization of the supervisor's role in carrying out the policies contained regarding pesticide control which must be realized to protect human health and safety, preserve nature and the environment, guarantee the quality and effectiveness of pesticides, and provide protection to procedures, pesticide dealer, and user [45].

\section{Conclusions}

Based on the research, it concludes that unsafe behavior in pesticide use among farmer caused by a lack of farmer's knowledge about pesticide's hazard. It happens cause the low of concerned and supported stakeholder for risk in pesticide use. The farmer has own decided in pesticide use and there was no controlling in continuously. They are free for use and act in unsafe behavior. To solve this, it needs collaboration and community participation to eliminate the risk of pesticide toxicity with empowering the community in safe behavior of pesticide use, informed of the community movement.

\section{Acknowledgements}

The authors would like to thank all farmers that participate and contribute to this study. Best regards for village leader Mr. Dinis Karo-Karo, community organizer Mr. Timur Tarigan and Mr. Japet Tarigan that supported making easier and great collaboration in founding the solution to solve the problems.

\section{References}

1. Prijanto TB, Nurjazuli N, Sulistiyani S. Analysis of risk factors for organophosphate pesticide poisoning in horticultural farming families in the Ngablak sub-district of Magelang district. J Kesehatan Lingkungan Indones. 2009;8(2):76-81. https://doi. org/10.14710/jkli.16.2.63-69

2. Eliza T, Tubagus $H$, Suriaty $S$. Farmer's behavior in the use of chemical pesticides (the case of chili farmers in the gisting complex of the Gisting sub-district of Tanggamus Regency). J IImu- IImu Agribisnis. 2013;1(4):334-42. https://doi. org/10.23960/jiia. v7i2.247-254
3. Wudianto R. Petunjuk Penggunaan Pestisida. Jakarta: Penebar Swadaya; 2011.

4. Soemirat J. Toksikologi Lingkungan. Jakarta: Rineka Cipta; 2003.

5. Mahyuni EL. Risk Factors in the use of pesticides against health complaints to farmers in the district of Berastagi, Karo District 2014. Kesmas. 2015;9(1):79-89. https://doi.org/10.12928/ kesmas.v9i1.1554

6. Novizan. Petunjuk Penggunaan Pupuk yang Efektif. Jakarta: Agromedia Pustaka; 2003

7. World Health Organization. World Health Statistics 2017 Monitoring Health for the SDGs, Sustainable Development Goals. Geneva: World Health Organization; 2017.

8. Kishi $M$, Hirschhorn $N$, Djajadisastra $M$, Satterlee $L N$, Strowman S, Dilts R. Relationship of pesticide spraying to signs and symptoms in Indonesian farmers. Scand J Work Environ Health. 1995;21(2):124-33. https://doi.org/10.5271/sjweh.19 PMid:7618058

9. Pawukir ES, Joko M. Hubungan antara pengunaan pestisida dan dampak kesehatan studi kasus di dataran tinggi sumatar barat. Manusia Lingkungan. 2002;9(3):126-36. https://doi. org/10.36568/kesling.v16i1.819

10. Dinas Kesehatan Kabupaten Karo. Data Pemeriksaan Cholinesterase Pengguna Pestisida Kabupaten Karo tahun 2008. Subdin P2P and PL. Indonesia: Dinas Kesehatan Kabupaten Karo; 2008. https://doi.org/10.31289/agrica. v10i2.1118

11. Mahyuni EL, Yustina I, Sudaryati E. Safety talk and check to prevent pesticide toxicity among farmer. Int J Public Health Sci. 2017;6(4):293-8. https://doi.org/10.11591/ijphs.v6i4.9113

12. Dinas Pertanian Karo. Data Kelompok Tani dan Data Produks Kabanjahe. Kabanjahe. Indonesia: Dinas Pertanian Karo; 2018.

13. Collison E, Hird H, Cresswell J, Tyler C. Interactive effects of pesticide exposure and pathogen infection on bee health a critical analysis. Biol Rev Camb Philos Soc. 2016;91(4):100619. https://doi.org/10.1111/brv.12206 PMid:26150129

14. Praktinya A. Dasar-dasar Metodologi Penelitian Kedokteran dan Kesehatan. Jakarta: Raja Grafindo Persada; 2011.

15. Lemeshow S, Hosmer DW Jr., Klar J, Lwanga SK. Besar Sampel Dalam Penelitian Kesehatan. Yogyakarta: Gadjah Mada University Press; 1997.

16. Dahlan SM. Besar Sampel dan Cara Pengambilan Sampe dalam Penelitian Kedokteran dan Kesehatan. Jakarta: Salemba Medika; 2013.

17. Yusuf AM. Metode Penelitian Kuantitatif, Kualitatif and Penelitian Gabungan. Jakarta: Prenadamedia Group; 2016.

18. Green LW, Marshall WK. Health Promotion Planning An Education Approach. $2^{\text {nd }}$ ed. London: Mayfield Publishing Company; 2000.

19. Arcury TA, Quandt SA. Pesticides at work and at home: Exposure of migrant farmworkers. Lancet. 2003;362(9400):2021. https:// doi.org/10.1016/s0140-6736(03)15027-1 PMid: 14686376

20. Engel LS, Hill DA, Hoppin JA, Lubin JH, Lynch CF, Pierce J, et al. Pesticide use and breast cancer risk among farmers' wives in the agricultural health study. Am J Epidemiol. 2005;161(2):12135. https://doi.org/10.1093/aje/kwi022 PMid:15632262

21. Alavanja MC, Hoppin JA, Kamel F. Health effects of chronic pesticide exposure: Cancer and neurotoxicity. Ann Rev Public Health. 2004;25(1):155-97. https://doi.org/10.1146/annurev. publhealth.25.101802.123020

PMid: 15015917

22. Deborah R. Are pests the problem or pesticides. Biol J. 
2006;28(1):6-7.

23. Banerjee I, Tripathi SK, Roy AS, Sengupta P. Pesticide use pattern among farmers in a rural district of West Bengal, India. J Nat Sci Biol Med. 2014;5(2):313-6. https://doi. org/10.4103/0976-9668.136173

PMid:25097405

24. Varona ME, Díaz SM, Briceño L, Sánchez-Infante $\mathrm{Cl}$, Torres $\mathrm{CH}$ Palma RM, et al. Determining social factors related to pesticide poisoning among rice farmers in Colombia. Rev Salud Publica. 2016;18(4):617-29.

PMid:28453066

25. London L, Nell V, Thompson ML, Myers JE. Health status among farm workers in the Western Cape Collateral evidence from a study of occupational hazard. S Afr Med J. 1998;88(9):1096-101. PMid:9798496

26. Abang A, Kouame C, Abang M, Hannah R, Fotso A, Author C. Vegetable growers perception of pesticide use practices, cost, and health effects in the tropical region of Cameroon. Int J Agron Plant Prod. 2013;4(5):873-83.

27. Yuantari MG, Widiarnako B, Sunoko HR. Tingkat Pengetahuan Petani dalam Menggunakan Pestisida (Studi Kasus di Desa Curut Kecamatan Penawangan Kabupaten Grobogan). Seminar Nasional Pengelolaan Sumberdaya Alam dan Lingkungan; 2013.

28. Budiawan AR. Risk factors associated with cholinesterase in onion farmers in starch injuries. Unnes $\mathrm{J}$ Public Health. 2014;3(1):1-11.

29. Suparti S, Anies, Setiani O. Some risk factors that influence the incidence of pesticide poisoning in farmers. J Pena Med. 2016;6(2):125-38. https://doi.org/10.36729/ jam.v4i2.218

30. Yuantari MG, Widianarko B, Sunoko HR. Analisis risiko pajanan pestisida terhadap Kesehatan Petani. J Kesehatan Masyarakat. 2015;10(2):239-45. https://doi.org/10.15294/kemas.v10i2.3387

31. Blanco-Muñoz J, Lacasaña M. Practices in pesticide handling and the use of personal protective equipment in Mexican agricultural workers. J Agromed. 2011;16(2):117-26. https://doi. org/10.1080/1059924x.2011.555282

32. Lu FC. Toksikologi Dasar (Asas, Organ Sasaran, dan Penilaian Risiko). Jakarta: Penerbit Universitas Indonesia; 2006.

33. Yarpuz-Bozdogan N. The importance of personal protective equipment in pesticide applications in agriculture. Curr Opin Environ Sci Health. 2018;4:1-4. https://doi.org/10.1016/j. coesh.2018.02.001

34. Hashimoto $H$, Yamada $K$, Hori $H$, Kumagai $S$, Murata $M$, Nagoya $T$, et al. Guidelines for personal exposure monitoring of chemicals: Part V. J Occup Health. 2018;60(3):203-7. https:// doi.org/10.1539/joh.2018-0060-ra

PMid:29669968

35. Lekei EE, Ngowi AV, London L. Farmers' knowledge, practices and injuries associated with pesticide exposure in rural farming villages in Tanzania. BMC Public Health. 2014;14(1):389. https://doi.org/10.1186/1471-2458-14-389 PMid:24754959

36. Budiyono N, Relationship between factors of insecticide exposure and pesticide poisoning in melon spraying farmers in Ngawi. J Kesehatan Masyarakat Indones. 2005;2(2):142-7. https://doi.org/10.14710/mkmi.19.1.38-42

37. Ipmawati PA, Setiani O, Danudianti YH. Analisis faktor faktor risiko yang mempengaruhi tingkat keracunan pestisida pada petani di desa jati, Kecamatan Sawangan, Kabupaten Magelang, Jawa Tengah. Kesehatan Masyarakat. 2016;4(1):427-35. https://doi.org/10.24903/kujkm.v2i1.303

38. Ruhendi D. Faktor determinan aktivitas kholinesterase darah petani holtikultura di Kabupaten Majalengka. Kesmas. 2008;2(5):215-9. https://doi.org/10.21109/kesmas.v2i5.254

39. Eddleston M, KarallieddeL, Buckley N, FernandoR, Hutchinson G, Isbister G, et al. Pesticide poisoning in the developing world a minimum pesticides list. Lancet. 2002;360(9340):1163-7. https://doi.org/10.1016/s0140-6736(02)11204-9

PMid:12387969

40. Kim KH, Kabir E, Jahan SA. Exposure to pesticides and the associated human health effects. Sci Total Environ. 2017;575:52535. https://doi.org/10.1016/j.scitotenv.2016.09.009 PMid:27614863

41. Sharifzadeh MS, Abdollahzadeh G, Damalas CA, Rezae R. Farmers' criteria for pesticide selection and use in the pest control process. Agriculture. 2018;8(2):1-16. https://doi. org/10.3390/agriculture8020024

42. Hernández AF, Parrón T, Tsatsakis AM, Requena M, Alarcón R, López-Guarnido O. Toxic effects of pesticide mixtures at a molecular level: Their relevance to human health. Toxicology. 2013;307:136-45. https://doi.org/10.1016/j.tox.2012.06.009

43. Schenker MB, Orenstein MR, Samuels SJ. Use of protective equipment among California farmers. Am J Ind Med. 2002;42(5):455-64. https://doi.org/10.1002/ajim.10134 PMid:12382259

44. Hilda A. Evaluasi Kebijakan Pengawasan Penggunaan Pestisida di Kabupaten Sidi. Katalogis. 2013;3(2):77-83.

45. Kementerian Pertanian Republik Indonesia. Keputusan Menter Pertanian Republik Indonesia No. 517 Tahun 2002 tentang Pengawasan Pestisida. Jakarta: Kementerian Pertanian Republik Indonesia; 2002. https://doi.org/10.31219/osf.io/vbpu7 